\title{
THE IMPROVEMENT OF EXCELLENT SERVICE THROUGH THE IMPLEMENTATION OF ONE-STOP SERVICE: A STUDY IN THE INTEGRATED LICENSING SERVICES OFFICE OF BREBES REGENCY, CENTRAL JAVA OF INDONESIA
}

\author{
Siswoyo Mukarto* \\ Department of Public Administration, Faculty of Social and Politics, \\ University of Swadaya Gunung Jati, Indonesia \\ Nugroho Setiawan \\ University of Swadaya Gunung Jati, Indonesia \\ *E-mail: mukartosiswoyougi@gmail.com
}

\begin{abstract}
This study aimed to describe the process of implementing one stop service and to describe the factors that influence the implementation of one stop service to improve excellent service at Integrated Licensing ServicesOffice of Brebes Regency. The research was conducted at Integrated Licensing Services Office of Brebes Regency with qualitative descriptive approach. Research targets are all concerned with the process of the implementation of one stop service to improve excellent service at research location. The sampling technique using a combination of purposive and snowball sampling techniques, through in-depth interviews, observation, documentation, and literature study while data analysis using an interactive model. The result of the study concluded that implementation of one stop service to improve excellent service at Integrated Licensing ServicesOffice of Brebes Regency has not been effective and has not been accordance with the one stop service guidelines. There are still obstacles in the implementation of which several types of licenses still in process at the technical office that prolong the licensing process, there is no integration with investment activities, license settlement overtime, standards of service, and institutions that do not fit the guidelines, and the limited of facilities and budgets. Factors that affect the implementation of one stop service to improve excellent service at Integrated Licensing ServicesOffice of Brebes Regency, among other factors, namely (1) communication, (2) resources, (3) the disposition and (4) the structure of the bureaucracy. These factors indicate the relationship between the factors and mutual influence on the process of implementation due to the constraint in these factors the implementation is not effective so that excellent service cannot be realized.
\end{abstract}

\section{KEY WORDS}

Implementation, one-stop service, excellent service, public service.

Services in the licensing sector do not escape the spotlight in its implementation, because licensing service is one of the forms of public services. Services in the licensing sector such as Building Construction Permits, Disturbance Permits, Location Permits, Advertising Permits, Trading Business Permits, and other permits that are the authority of the regional government are one form of public service included in the administrative service group. In its implementation, public services in some regions are still often characterized by service problems that make it difficult to be accessed by the public. There are still a lot of inadequate service provisions including those related to licensing services. Good quality of public service is still far from the expectations, for which there is still full service with bureaucracy that is convoluted, complicated, slow, expensive, and tiring.

In order to overcome the problems in the licensing services sector and provide convenience and ease for the public, business people, and investors in managing permits, the government issued One Stop Service (OSS) policy that is first regulated by Minister of Home 
Affairs Regulation No. 24 of 2006 concerning Guidelines Implementation of One-Stop Services. In the regulations, it is explained that the Implementation of One-Stop Services is licensing and non-licensing service activities which management process starts from the application stage until the document issuance stage is carried out in one place.

The government of Brebes Regency responded to the government's policy regarding OSS through the Regent's Regulation No. 006 of 2006 concerning The Establishment of Organization and Work Procedure of Brebes Regency Integrated Service Office. The Integrated Service Office (ISO) is the beginning of the establishment of a one-stop service (OSS) unit in Brebes Regency. In its development, the name of organization of regional apparatus was carried out with the issuance of Regional Regulation of Brebes No. 7 of 2008 concerning Organization and Work Procedure of Regional Technical Institutions, Inspectorates, Civil Service Police Units, and Other Institutions of Brebes Regency. In the regional regulations, there are changes in organization and work procedures from the Integrated Service Office (ISO) to the Integrated Licensing Service Office (ILSO/KPPT) of Brebes Regency.

After the ILSO of Brebes Regency was formed and carried out its duties for approximately 10 years, there were several problems in its implementations based on the initial observations from researchers. The problems include the implementation of licensing services that are less effective, such as the granting of Building Construction Permits, Public Transportation Route Permits, Tourism Business Registration, and Establishment of Health Facilities Permits for clinics and hospitals, where applicants must get technical recommendations from related agencies/institutions first and then arrange permission from the ILSO. This is certainly very troublesome for the applicant, because they have to go back and forth to several places first to get their early permission before submitting requests for permission to the ILSO.

Another problem is that the implementation of OSS by the regency/city government according to Presidential Regulation No. 97 of 2014 concerning the Implementation of OSS is carried out by Regency/City One-Stop Services and Investment Service, but in Brebes Regency, until today it is still in the form of an office, which is the Integrated Licensing Service Office (ILSO).

In the initial observation, researchers also found that there were licensing issues related to spatial planning, as written in suaramerdeka.com in October 2, 2014 with the title of 'Garment Development in Brebes was stopped by Local Authorities'. It happened because they did not have Building Construction Permits and was considered violating its land use. In brebesnews.co, on March 20, 2014, there was an article entitled '38 Local and Foreign Investors was hampered by Brebes Regional Regulations'. In this article, it was stated that when applying for company licenses, the company argued that the land they occupied was unproductive rice fields, which in the regional regulations it included in the spatial layout of the industrial area, yet suddenly there were many residential settlements which had not yet own the Building Construction Permits. These finding indicate that there is a lack of public order towards licensing and lack of supervision by the authorities on the activities of building construction. Some of these problems can provide a preliminary description that the implementation of one-stop service carried out by the Integrated Licensing Service Office of Brebes Regency is still faced with problems or obstacles in its implementation. Based on the background of the problem mentioned above, the research problems are:

- How does the implementation of one-stop service in the Integrated Licensing Service Office of Brebes Regency?

- What factors influence the implementation of one-stop services in the Integrated Licensing Service Office of Brebes Regency?

\section{LITERATURE REVIEW}

Public service is defined as all forms of public service activities carried out by government agencies at the state, regional, and in state/regional business entities in the form of goods and services, both in the context of efforts to fulfill community needs and in the 
implementation of statutory provisions (Hartati, et al., 2013). Based on Law No. 25 of 2009 concerning Public Services, public service is carried out by public service providers, namely every state administering institutions, corporations, independent institutions established by law for public service activities, and other legal entities formed solely for public service activities. Sinambela (2011) stated that public services is the fulfillment of people's wants and needs by state administrators that is established to improve welfare and satisfy the public as service users. This satisfaction can be achieved by providing excellent service, namely services that are open, easy, accessible to all parties in need, provided adequately, and easily understood (Ismayanti, 2015). Ginting, et al. (2018) added that public service quality is related to organizational capabilities in serving the community. Therefore, it needs to be managed properly through excellent service management.

The improvement of service quality is needed in all sectors of the organization, including public sector organizations. The concept of quality according to Gaspersz (2005) is conventionally interpreted as a description of the direct characteristics of a product such as performance, reliability, ease of use, and aesthetics. Strategically, quality is interpreted as everything that is able to meet customer desires or needs.

According to Fryer, et al. (2007), the improvement of service quality is necessary since organizations are always faced with higher demands along with demographic and social changes that occur. Organizations are asked to give their best and are required to always increase their accountability and transparency. Boyne (2003) explained that the improvement of public service is a dynamic phenomenon, inherently raises questions about justice, and is usually related to the performance of multi-organizational networks rather than the achievement of a single organization.

Boyne (2003) divided the improvement of public service quality into five models, namely: (1) the goal model, which emphasizes changes in substantive standards of service; (2) the resource-system model, which focuses on the capacity of service providers to obtain technical input from their environment; (3) internal process model, which shows that most attention must be given to how these inputs are used in the organization; (4) competing values model, which tries to combine all of these perspectives into a universally valid set of evaluative criteria; and (5) the multiple consistency model, which implies that improvement exists only in the eyes of organizational stakeholders.

The hierarchical and long bureaucratic structure is considered to be an obstacle for the community to fulfill their needs in various specific fields. One of the efforts made by the government to improve excellent service in public sector organization is one-stop service, which is the pattern of public services that carried out in an integrated manner in a place by several government institutions in accordance with their specific authorities.

According to Trochidis, et al. (2008), an integrated public service system promises smooth service delivery from various government organizations and create efficiency and experience of service for service providers as well as service users themselves. This model is called one-stop service, one-stop government, or single access point, which is the integration of public service from the point of view and interests of the community or customers (Kubicek \& Hagen, 2001).

Ginting, et al. (2018) describes the pattern of one-stop service as a type of service that has a process linkage and is served through one door. This type of service can be done more quickly and efficiently, because it can be processed in parallel, administratively and technically held on one roof and one door.

\section{METHODS OF RESEARCH}

In this study, researchers used descriptive qualitative approach that usually is used to answer the question "how" and "why", which in principles is to find detailed answers through in-depth interview (Hamidi 2010:11). With this qualitative research method, researchers hope to be able to describe the process of policy implementation regarding OSS and to find the factors that influence the implementation of OSS in the Integrated Licensing Service Office of Brebes Regency. In this study, to select informants, researchers refer to a combination of 
purposive and snowball sampling technique with the aim of obtaining objective data in accordance with the real condition in the field.

In selecting the informants, researchers tend to choose informants who are considered to know the most and can be trusted to be a steady source of data and know the problem as a whole. Furthermore, to get the expected amount and quality of data, the researchers used a combination of purposive and snowball sampling technique to capture informants from the apparatus of Integrated Licensing Service Office of Brebes Regency who are directly involved with licensing service and aware of the problems that is investigated. After the interview is considered sufficiently appropriate, the key informants will appoint other informants who are seen to know more about the problem. In this study, researchers determined the head of Integrated Licensing Service Office of Brebes Regency as key informants. In addition to the key informants, researchers also determined supporting informants such as structural officers and officers/staff Sections of Integrated Licensing Service Office of Brebes Regency, members of the licensing technical team from the related office, and applicants for licensing service at Integrated Licensing Service Office of Brebes Regency.

The data required for this study is collected through several techniques, namely:

1. In-depth Interview;

2. Observation;

3. Documentation;

4. Literature Study.

In this study, researchers used data analysis interactive analysis model. The data analysis process using an interactive analysis model includes data collection, data reduction, data presentation, and drawing conclusions with the aim to understand the observed phenomena and answer the problems that have been formulated.

\section{RESULTS AND DISCUSSION}

One-Stop Service (OSS) Policy was first regulated in the Minister of Home Affairs Regulation No. 24 of 2006 concerning Guidelines for Implementing One-Stop Services. The implementation of the policy was then strengthened by several rules, namely Minister of Home Affairs Regulation No. 20 of 2008 concerning Organization Guidelines and Work Procedures for Integrated Licensing Service Units in Regions, Law No. 25 of 2009 concerning Public Services, and Presidential Regulation No. 97 of 2014 concerning Implementation of One-Stop Services.

OSS is one of the public service models that seek to respond to complaints of community dissatisfaction, because with OSS obtaining permits can be done only in one office. Therefore, applicants do not need to spend a lot of money, time, and effort to complete the permit.

The implementation of OSS in Brebes Regency is carried out by Integrated Licensing Service Office of Brebes Regency which was formed based on the Regional Regulation of Brebes Regency No. 7 of 2008 concerning Organization and Work Procedure of Regional Technical Institutions, Inspectorates, Civil Service Police Units and Other Institutions of Brebes Regency, with principal to coordinate and administer licensing administrative services in an integrated manner with the principles of coordination, integration, synchronization, simplicity, security, and certainty.

The initial observation from researchers shows that there is no consistency in regional apparatus organization as the organizers of OSS in Brebes Regency, which is still in the form of office, while the guidelines stated that it must be in the form of Regency/City One Stop Investment and Integration Service. Based on the Government Regulation No. 18 of 2016 concerning Regional Working Unit Organization, it also should be in the form of official service. In addition, there is no integration between investment activities and licensing service activities, since the investment issues is handled by the Regional Development Planning Agency while the licensing services are carried by the OSS. 
The implementation of OSS by the Integrated Licensing Service Office of Brebes Regency is still done in the form of office, but in carrying out its main tasks and functions, it is already in accordance with OSS principle, such as integration proven by being the only licensing service starting from the application, processing, up to licensing that is carried out through one door at the Integrated Licensing Service Office of Brebes Regency.

However, in this study, researchers still found some requirements for recommendation in the technical office for several permits that made it more difficult for applicants and extend the process of obtaining permits, although the recommendations is considered as a complete requirement. In the practice, the applicant must go to two places: technical office to arrange recommendations, and then the OSS to continue the licensing process.

The Integrated Licensing Service Office of Brebes Regency has service standards for providing licensing services as determined based on the Decree of the Head of the Integrated Licensing Service Office of Brebes Regency No. 068.2/740 of 2012 on November 30,2012 . The service standard of the office was determined before the issuance of Presidential Regulation No. 97 of 2014. It means that there are no changes or adjustment to the new rules as well as in terms of requirements and service products that have been made since the enactment of the Presidential Regulation until the time this research was conducted.

In carrying out its duties, the Integrated Licensing Service Office of Brebes Regency has some constraints, namely the small budget for field inspection activities, limited personnel/employees, limited operational vehicles for field checks, and vary distance between subdistricts. If the entire permit application is carried out in a field inspection, it will result in the length of the permit settlement process. However, if the location inspection is not carried out, it will conflict with the rules and it can lead to problems in the future because of lack of support with the complete field data.

Based on the data of the period of permit completion, it can be seen that the fastes completion time is 1 working day while the longest is 12 working days. In fact, the Presidential Regulation No. 97 of 2014 stated that the OSS service period is set to no later than 7 working days. Based on the data of the Information System of the Integrated Licensing Service Office of Brebes Regency from January to November of 2016, the number of licenses issued was 5.669 permits. From the number issued, there are 1.018 licenses whose permit completion time exceeds a predetermined period of time, or $17.96 \%$ of the licenses issued exceed the period of completion of the permit.

Furthermore, the distance between subdistricts and the Integrated Licensing Service Office of Brebes Regency becomes another problem in the implementation of OSS. In order to administer permits, people who lived in the southern region must travel tens of kilometers, which also requires costs and travel time.

The implementation of OSS is required to use Electronic Services in accordance with Article 17 of Presidential Regulation No. 97 of 2014 which includes the automation of work processes (business processes) and information needed in Licensing and Non-Licensing services. The implementation of OSS through Electronic Services is considered not ready to be implemented by the researchers due to the lack of readiness from the OSS providers at the regional level who will manage and ensure that the Electronic Services operate continuously according to service level standards, data and information security, as well as the absence of implementation provisions through the Ministry of Home Affairs Regulation.

In this study, to find out the factors that influence the implementation of the policy, researchers use policy implementation model according to George C. Edward IIlwho stated that there are 4 variables that influence the success of policy implementation, namely communication, resources, disposition, and bureaucratic structure.

In communication, there three important things, which are: transmission, consistency, and clarity. The OSS policy have been going on since 2006, and until today, the policy has been socialized by the central government to regional government through various forms of activities, such as socialization, National OSS Forum, and Provincial OSS Forum which are held regularly, as well as through OSS Technical Guidance held by the Ministry of Home Affairs, and OSS Investment Guidance held by the Investment Coordination Board. 
In general, the communication of OSS service from the central government, which in this case is the Ministry of Home Affairs and the Investment Coordination Board to the Government of Brebes Regency, has been going well. In terms of transmission, the guidelines or instructions for OSS both based on Minister of Home Affairs Regulation No. 24 of 2006 and Presidential Regulation No. 97 of 2014 can be understood and implemented by the apparatus in Brebes Regency. It can be seen by the ongoing operation of OSS in Brebes Regency from 2006 to this time.

In terms of consistency, the OSS policy does not conflict with other rules, and it even supports the success of public service policies. This can be seen from what becomes the goal of OSS, such as shortening the service process, realizing services that are fast, easy, inexpensive, transparent, certain, and affordable.

On the other hand, the socialization carried out by the Integrated Licensing Service Office of Brebes Regency to the community is considered ineffective due to budget constraints. In fact, the socialization can be done every year in each subdistrict by inviting participants from villages in the sub districts. It would even be better if the socialization is carried out at the village, so that it could reach all business actors or communities who needed licensing information. The discussion of the transmission, consistency, and clarity proves that communication is very necessary and important in implementing a policy.

In the implementation of the policy, even though the point of the policy has been communicated clearly and consistently, if the implementers experience lack of resources to implement the policy, the implementation will not be able to run effectively. Important sources can include adequate and competent staff, authority, information, and supporting facilities.

Based on the data of number of employees in the Integrated Licensing Service Office of Brebes Regency and interview results, researchers observed that the composition of $60 \%$ civil servants employees and $40 \%$ of contract workers employees would certainly hinder the implementation of the OSS. From the total number of the employees, there are only 10 people who have undergraduate and diploma education qualifications, but they also cannot guarantee that they have competencies that are in accordance with their main tasks and functions. The shortage number of the employee is also known from the results of the workload analysis carried out by Integrated Licensing Service Office of Brebes Regency in 2016 which showed a shortage of staff.

The second resource required in the implementation of the policy is authority. Although in Brebes Regency the OSS implementation is only carried out by the office, in the practice, the Regent of Brebes had carried out delegation of almost all of the licensing authority to the Head of Integrated Licensing Service Office of Brebes Regency which is stated in the Regulations of Brebes Regent No. 005 of 2016.

The next resource related to the implementation of the policy is facilities. Facilities in the form of equipment and supplies are used to support work in implementing a policy. From the researchers' observation, the Integrated Licensing Service Office of Brebes Regency already has service rooms/counters, except that in its implementation for payment and submission of documents is provided in one place and served by only one staff members. The same thing also happens for the complaints handling site that becomes one place with the place of submission request and information due to limited staff. Besides that, there are still some shortcomings that could hamper the implementation of the service, such as lack of operational service vehicles used for field checks, and printers that often experience problems due to high activity in printing permit documents. Another obstacle is that the office building facility that is inadequate for vehicles parking.

Another important resource is budget support. From the interview result with some of the informants, it can be concluded that there are still limited budgets owned by the Integrated Licensing Service Office of Brebes Regency, especially for official travel budget checks, socialization activities, and licensing monitoring. From the description above, it can be stated that the existence of resources is something that is important in the implementation of policies, because without adequate resources, the implementation would not be able to run well. 
The third variable from the implementation of the policy is disposition or attitude of the apparatus. In the Integrated Licensing Service Office of Brebes Regency, the front office officers have been able to carry out their duties properly. It is also supported by the information from permit applicants who stated that the service officer has been able to provide an explanation of licensing properly and has provided service kindly. In applying for permission applications, the applicants were directly served by the officer. The good attitudes of service officers are also proven by the results of the Community Satisfactory Index of Integrated Licensing Service Office of Brebes Regency in Semester 2 of 2016 to applicants for licensing. The result shows that, in general, the service quality for licensing units at Integrated Licensing Service Office of Brebes Regency is perceived well by the user community.

The last variable is bureaucracy with two main characteristics, namely: Standard Operating Procedure (SOP) and fragmentation. The Integrated Licensing Service Office of Brebes Regency already has an SOP as written in the Service Standards ofIntegrated Licensing Service Office. However, as discussed earlier, the Service Standards that is established in 2012 is old and there is no change or adjustment that has been made to the new legislation. Thus, it can be stated that the SOP is incompatible with current conditions, and adjustments need to be done immediately.

As for fragmentation, the worst consequence of bureaucratic fragmentation is that the implementers with the reason of different scale of program priority from different bodies encourage avoiding coordination with other agencies.

With the issuance of Presidential Regulation No. 97 of 2014, the organization structure of the Integrated Licensing Service Office of Brebes Regency should be adjusted to become Regency/City One-Stop Services and Investment Service. In its development, with the issuance of Government Regulation No. 18 of 2016 concerning Regional Work Unit, the organizational structure of OSS organizers underwent changes into the Investment Office and One Stop Service (OSS). The OSS administrators at the Regency/City Government level should be in echelon II position in form of an official service office in accordance with what is written in the Government Regulation No. 18 of 2016. It needs to be done to facilitate coordination with other technical agencies because in carrying out their duties they need the role from other technical institutions. This also added by the existence of the Licensing Technical Team residing in each technical agency and did not settle at the Integrated Licensing Service Office of Brebes Regency. This will lead to fragmentation of the organizational structure that will tend to difficult the coordination, so that the existence of the technical team needs to be reviewed or improved in terms of regulations at the central government level and with coordination in implementing tasks at the local government level, for example by permanently placing the Technical Team at the Integrated Licensing Service Office of Brebes Regency.

\section{CONCLUSION AND RECOMMENDATIONS}

The implementation of OSS in Brebes Regency which has been implemented since 2006 can be said to be ineffective since some of the practices include: several types of licenses that process in technical services office, there is no integration with investment activities, and there are several types of license that is processed for more than 7 working days, and licensing completion exceed the permit completion time.

The implementation of OSS in Integrated Licensing Service Office of Brebes Regency is influenced by the factors as follows:

a. Communication. The OSS policy has been communicated by the central government to regional government. However, there are unclear instructions about Electronic Services and the socialization that should be done by the Integrated Licensing Service Office of Brebes Regency has not been maximized due to budget constraints.

b. Resource. The Integrated Licensing Service Office of Brebes Regency has limitations in terms of staff, facilities, and a very minimal budget for field inspection, 
socialization, and licensing monitoring activities. However, the authority has received delegation of almost all of the licensing authority from the Regent of Brebes.

c. Disposition. The attitude of service officers in general is good and friendly, although the employees do not have incentives in the form of special allowances.

d. Bureaucratic Structure. The organization of OSS is still in the form of office, while according to the Government Regulation No. 18 of 2016 it should be in the form of official service office. The Integrated Licensing Service Office of Brebes Regency already has an SOP contained in the Service Standards, but it is incompatible with current conditions. In addition, coordination with technical agencies and the existence of the Licensing Technical Team still become the obstacles in the implementation of licensing services.

\section{REFERENCES}

1. Boyne, G. A. 2003. What is Public Service Improvement? Public Administration Vol. 81 No. 2 pp. 211-227. Blackwell Publishing Ltd, USA.

2. Fryer, K. J., Antony, J., Douglas, A. 2007. Critical Success Factors of Continuous Improvement in the Public Sector: A Literature Review and Some Key Findings. The TQM Magazine. Vol. 19, No. 5, pp. 497-517.

3. Gaspersz, V. (2005). Total Quality Management, PT. Gramedia Pustaka Umum, Jakarta.

4. Ginting, L.M., Susanti, E., \&Sumaryana, A. 2018.Implementasi Pelayanan Terpadu Satu Pintu Non-Perizinan Diukurdari Kepuasan Masyarakatdengan Menggunakan Indeks Kepuasan Masyarakat. Responsive, Vol. 1 No. 2, pp.44-55.

5. Hamidi. (2010). Metode Penelitian Kualitatif. Pendekatan Praktis Penulisan Proposal and Laporan Penelitian. Malang: UMM Press.

6. Hartati, S., Herawati, N., \&Listiani, E.S. 2013. Kinerja Organisasi Pelayanan Publikpada Kantor Pelayanan Terpadu Satu Pintu Kabupaten Sintang. Jurnal Tesis PMIS-UNTANSPSIAN.

7. Ismayanti, L. 2015. Efektivitas Penyelenggaraan Pelayanan Terpadu SatuPintu di Kabupaten Malang. Jurnalllmu Sosialdan IImu Politik, Vol. 4, No. 2, pp 290-300.

8. Kubicek, H., \& Hagen, M. (2001).Integrating e-commerce and e-government: The Case of Bremen Online Services. LAW AND ELECTRONIC COMMERCE, Vol. 12, pp. 177-196

9. Sinambela, L.P. 2011. Reformasi Pelayanan Publik: Teori, Kebijakan, danlmplementasi. Edisi Keenam. Bumi Aksara, Jakarta.

10. Sugiyono. 2005. Memahami Penelitian Kualitatif. Bandung: Alfabeta.

11. Trochidis, I., Tambouris, E., \& Tarabanis, K. 2008. One-stop government: A literature review. In proceedings of the $6^{\text {th }}$ Eastern European eGov Days (eGov Days) conference, Prague, Czech Republic.

12. Undang-undang Nomor 25 Tahun 2009 tentang Pelayanan Publik.

13. Peraturan Presiden Nomor 97 Tahun 2014 tentang Penyelenggaraan Pelayanan Terpadu Satu Pintu.

14. Peraturan Pemerintah Nomor 18 Tahun 2016 tentang Organisasi Perangkat Daerah

15. Peraturan Menteri Dalam Negeri Nomor 24 Tahun 2006 tentang Pedoman Penyelenggaraan Pelayanan Terpadu Satu Pintu.

16. Peraturan Menteri Dalam Negeri Nomor 20 Tahun 2008 tentang Pedoman Organisasi and Tatakerja Unit Pelayanan Perijinan Terpadu di Daerah.

17. Peraturan Daerah Kabupaten Brebes Nomor 7Tahun 2008 tentang Organisasi and Tata Kerja Lembaga Teknis Daerah, Inspektorat, Satuan Polisi Pamong Praja and Lembaga Lain Kabupaten Brebes.

18. Peraturan Bupati Brebes Nomor 006 Tahun 2006 tentang Pembentukan Organisasi and Tata Kerja Kantor Pelayanan Terpadu Kabupaten Brebes.

19. Peraturan Bupati Brebes Nomor 005 Tahun 2016 Tentang Pendelegasian Wewenang Kepada Kepala Kantor Pelayanan Perizinan Terpadu Kabupaten Brebes. 